\title{
Characterization of Sand and Zeolite Stabilized Expansive Soil as Landfill Liner Material under Environmental and Climatic Effects
}

\author{
Şerife Önc $\ddot{\mathrm{u}}^{1, *}$ and Huriye Bilsel $^{2}$ \\ ${ }^{1}$ Eastern Mediterranean University \\ ${ }^{2}$ Cyprus International University
}

\begin{abstract}
This study focusses on the assessment of sand stabilized expansive soil as possible landfill liner materials to be utilized in a semi-arid area. Zeolite was also used as an alternative material to sand, mixing it with the expansive soil forming a stable structure with improved properties. Durability analysis of expansive soil-sand (NS) and expansive soil-zeolite (NZ) mixtures was studied to investigate the climatic and environmental effects on the sustainability of the proposed materials. The climatic effect is studied in terms of cyclic swell-shrinking and the environmental effect, mainly due to temperature elevations in the landfills, is studied in swell-compressibility tests. Cyclic swell-shrink tests and temperature variations $\left(25^{\circ} \mathrm{C}, 40^{\circ} \mathrm{C}\right.$ and $\left.60^{\circ} \mathrm{C}\right)$ were applied on 28 -day cured samples of NS and NZ mixtures in order to evaluate their resistance to climatic and environmental changes. Experimental findings showed that swelling potential and axial shrinkage were reduced with the increasing of wetting-drying cycles of both NS and NZ samples. The biggest variation of swell potential and axial shrinkage occurred at 7th cycle for NS (28-d) and 8th cycle for NZ (28-d) soil specimens. Primary swell percentage decreased with the increase of temperature in NS group, whereas, a reverse behavior was observed in NZ group.
\end{abstract}

\section{Introduction}

Seasonal changes cause moisture variations of soil water, increasing in the wet season and decreasing in the dry season. Evaporation of soil water during drying period causes volume shrinkage and desiccation cracks to occur. Swelling and shrinkage are the most important parameters in the investigation of volume change properties of expansive soils. Several factors affect shrinkage and cracking such as clay mineralogy, clay content, compaction conditions, temperature changes, cyclic wetting and drying, soil particle orientation, moisture and density conditions. Temperature changes have great impact on the behavior of compacted soil, mainly when landfill barrier materials are subjected to elevated temperatures due to bio-chemical reactions of the waste contained.

\subsection{Background}

\subsubsection{Cyclic Swell-Shrink}

In the literature, several researchers studied the influence of the wetting and drying cycles on the swelling potential of clays. They deduced that clay samples showed a fatigue behavior after each wetting and drying cycle, therefore swelling ability is reduced [1-8]. Dif and Bluemel (1991) [7] indicated that the fatigue of expansive soils depends on three factors which include the clay mineral type, deterioration of clay structure due to particle reorientations and the lateral confinement loss when cracks occur. On the other hand, some researchers determined converse opinion about cyclic swelling. Popescu (1980) [9], Osipov et al. (1987) [10] and Day (1994) [11] concluded that the swelling potential increases with the number of wetting and drying cycles, which eventually reaches an equilibrium state. According to Popescu (1980) [9] the equilibrium state is reached after the fifth cycle. Al-Homoud et al. (1995) [8] recorded that the change of swelling completed between the fourth and fifth cycles. Bilsel and Tuncer (1998) [12] stated that a considerable increment in swell was observed at the end of fourth cycle.

Influence of aging (7, 15, 30 and 90 days) on the swelling potential and cyclic swell-shrink of expansive soil was examined by Rao and Tripathy (2003) [13] and deduced that aging caused a reduction in the swelling potential. According to this study, the cyclic swell-shrink eliminated the effect of aging when subjected to higher strains. However, aging was found to be effective at lower shrinkage strains. Rao et al. (2001) [14] studied the effect of wetting and drying cycles on the swelling character of ash-modified soils and lime-treated black cotton soils by performing four cycles. They stated that the effectiveness of lime partially disappeared after 4 cycles of wetting and drying in lime-treated black cotton soils which caused disruption of the cemented 
aggregates. Akcanca and Aytekin (2012) [15] studied sand-bentonite mixture in the form of unstabilized and lime stabilized soil groups exposed to 5 wetting-drying cycles. They found that swelling pressures of sandbentonite mixtures were decreased with the addition of lime, and suggested utilization of lime treated sandbentonite mixtures in the sanitary landfill liners which were prone to wetting-drying cycles.

Various procedures were implemented for drying process of the soil samples. Desiccating soil specimens by air drying under sunshine or room temperature were studied by $[8,11,16,17,18,19]$. Dif and Bluemel (1991) [7] performed the desiccation process by air drying under the surcharge pressures of $2-4 \mathrm{kPa}$. Rao and Satyadas (1987) [6] and Tripathy et al. (2002) [20] provided the intended temperature around the oedometer cell for each drying stage. Also, cyclic swell-shrink tests were carried out by using modified fixed ring oedometer cell with $50 \mathrm{kPa}$ surcharge pressure and each shrinkage cycle was done under a temperature of $40 \pm 5^{\circ} \mathrm{C}$ [21]. Drying temperature was used at $35 \pm 5^{\circ} \mathrm{C}$ in the studies of $[15,22]$.

\subsubsection{Influence of Temperature on Swell and Consolidation}

Lloret and Villar (2007) [23] stated that the swelling capacity of compacted bentonite reduced with temperature from $30^{\circ} \mathrm{C}$ to $80^{\circ} \mathrm{C}$, which could be explained with the effect of temperature on water affinity. Hence decrease of swelling pressure was observed as a function of temperature. Romero et al. (2005) [24] investigated the swelling strain of bentonite with a temperature range of $30^{\circ} \mathrm{C}$ to $80^{\circ} \mathrm{C}$ and observed that first heating caused an irreversible change in the clay macrostructure due to aggregate volume changes. This could be explained by the aggregate thermal expansion as well as the structural disturbance of the interlayer water lattice in smectitic clays, causing aggregate contraction due to grouping of packs of flakes, and favoring the transition from adsorbed water to free water. Furthermore they have concluded that with elevated temperatures, two reverse mechanisms occur at aggregate scale which are volume increase caused by thermal expansion of mineral particles and adsorbed water, and reduction in volume due to water losses in intra-aggregate.

Estabragh et al. (2016) [25] deduced that swell parameters, which include swell potential and swell pressure are functions of temperature as well as the duration it prevails. Increment of the temperature and duration of heating is efficient for the decrease of the swelling behavior. Villar et al. (2010) [26] studied the change of swelling pressure, swelling capacity and hydraulic conductivity at the temperature interval of $30^{\circ} \mathrm{C}$ to $90^{\circ} \mathrm{C}$. They reported that the reduction of swelling capacity of bentonite is indistinctly with the increasing temperature while there is a marked decrease observed in swelling pressure. On the other hand, the saturated hydraulic conductivity increases with the temperature.
Shariatmadari and Saeidijam (2011) [27] performed swell test with three temperatures $\left(25^{\circ} \mathrm{C}, 55^{\circ} \mathrm{C}\right.$ and $90^{\circ} \mathrm{C}$ ) and found that swelling reduces with the increasing temperature. Swelling decreased by $20 \%$ from $25^{\circ} \mathrm{C}$ to $90^{\circ} \mathrm{C}$. Compressibility increased at higher temperatures. Lloret and Villar (2007) [23] performed the compression test by applying $25^{\circ} \mathrm{C}, 40^{\circ} \mathrm{C}$ and $60^{\circ} \mathrm{C}$ temperature and found that the compressibility of bentonite increases as the temperature increases. Delage et al. (2010) [28] observed that the compressibility of clays are independent with the variations of temperature. Kholghifard et al. (2014) [29] performed the consolidation test on residual granitic soil with the temperatures of $27^{\circ} \mathrm{C}, 40^{\circ} \mathrm{C}$ and $60^{\circ} \mathrm{C}$ and concluded that the compression index does not depend on the temperature.

Cho et al. (1999) [30] examined the influence of temperature on the hydraulic conductivity of compacted bentonite. They made the tests at different temperatures $\left(20^{\circ} \mathrm{C}, 40^{\circ} \mathrm{C}, 60^{\circ} \mathrm{C}\right.$ and $\left.80^{\circ} \mathrm{C}\right)$ and found that the hydraulic conductivity increases as the temperature increases. Villar and Lloret (2004) [31] indicated that the swelling capacity of clay decreases at high temperatures yet this behavior is less evident under high vertical stresses. Similarly, a decrease in swelling pressure was also observed in relation to temperature. Conversely, the effect of temperature on permeability is small and slightly lower than what would be expected contrary to the thermal changes in water kinematic viscosity.

The aim of the study is to investigate the climatic (wetting-drying) and environmental (elevated temperatures in the landfill containment) effects on the durability and the stability of expansive soil-sand mixture (NS) and expansive soil-zeolite mixture (NZ).

\section{Materials and Methods}

\subsection{Materials}

Expansive soil was collected from Nicosia, and beach sand from Famagusta coast, Cyprus, while zeolite was obtained from Ege Zeolit Ltd., Bigadiç, Turkey. Physical properties of the expansive soil and zeolite, which are Atterberg limits (ASTM D4318-10e1), specific gravity (ASTM D854-14), linear shrinkage (BS 1377-2:90), and particle-size distribution (ASTM D422-63e2) are as presented in Table 1. The expansive soil is classified as silt with high plasticity (MH) according to the Unified Soil Classification System (ASTM D2487-11). Sieve analysis test results showed that effective grain size $\left(D_{10}\right)$ is 0.16 , median grain size $\left(D_{50}\right)$ is 0.19 , and coefficients of uniformity $\left(\mathrm{C}_{\mathrm{u}}\right)$ and curvature $\left(\mathrm{C}_{\mathrm{c}}\right)$ are 1.25 and 1.013 respectively. According to these results sand is classified as poorly graded uniform sand (SP). Zeolite includes nearly equal amounts of silt and sand-sized particles, with a small amount of clay-sized particles. The chemical composition is determined by X-ray flourescence (XRF) spectrometer and listed in Table 2. Zeolite contains a total percentage of $\mathrm{SiO}_{2}, \mathrm{Fe}_{2} \mathrm{O}_{3}$, and 
$\mathrm{Al}_{2} \mathrm{O}_{3}$ of more than $70 \%$, which is the necessary condition for a material to be evaluated as a pozzolan (ASTM C618-15).

Table 1. Physical properties of expansive soil and zeolite.

\begin{tabular}{|l|c|c|}
\hline $\begin{array}{l}\text { Physical } \\
\text { properties }\end{array}$ & $\begin{array}{c}\text { Expansive } \\
\text { soil (N) }\end{array}$ & $\begin{array}{c}\text { Zeolite } \\
(\mathbf{Z})\end{array}$ \\
\hline Liquid limit (\%) & 65 & 41 \\
\hline Plastic limit (\%) & 36 & 29 \\
\hline Plasticity index (\%) & 29 & 12 \\
\hline $\begin{array}{l}\text { Linear shrinkage } \\
(\%)\end{array}$ & 18 & 8 \\
\hline Specific Gravity & 2.69 & 2.35 \\
\hline Clay size (\%) & 43 & 15 \\
\hline Silt size (\%) & 50 & 41 \\
\hline Sand size (\%) & 7 & 44 \\
\hline
\end{tabular}

Table 2. Chemical properties of expansive soil and zeolite.

\begin{tabular}{|c|c|c|}
\hline $\begin{array}{c}\text { Chemical } \\
\text { Composition (\%) }\end{array}$ & $\begin{array}{c}\text { Expansive } \\
\text { soil (N) }\end{array}$ & $\begin{array}{c}\text { Zeolite } \\
(\mathbf{Z})\end{array}$ \\
\hline $\mathrm{SiO}_{2}$ & 36.5 & 61.7 \\
\hline $\mathrm{CO}_{2}$ & 17.9 & 7.05 \\
\hline $\mathrm{CaO}$ & 16.2 & 4.69 \\
\hline $\mathrm{Al}_{2} \mathrm{O}_{3}$ & 11.8 & 12.7 \\
\hline $\mathrm{Fe}_{2} \mathrm{O}_{3}$ & 6.87 & 1.58 \\
\hline $\mathrm{MgO}$ & 6.26 & 2.18 \\
\hline Other elements & 4.47 & 10.1 \\
\hline
\end{tabular}

The samples were tested in two groups, which were expansive soil-sand mixture (NS) and expansive soilzeolite mixture (NZ). These soil groups are mixed in 1:1 ratio and laboratory tests were performed on NS and NZ soil groups at 0 and 28 days curing period.

\subsection{Methods}

In this study, 28-day cured samples of NS and NZ were selected for performing cyclic swell-shrink test. Compacted soil samples of NS and NZ were prepared by using standard Proctor energy (ASTM D698-12e2) in their optimum water content and maximum dry densities with the dimensions of $75 \mathrm{~mm}$ diameter and $15 \mathrm{~mm}$ height. These specimens were wrapped carefully with nylon membranes and stored in a desiccator for 28 days. When 28 days curing period completed, one-dimensional swell tests (ASTM D4546-14) were started in a temperature controlled room $\left(25^{\circ} \mathrm{C}\right)$. Swelling tests were done under $7 \mathrm{kPa}$ surcharge pressure and the dial gauge readings were taken every day. When the readings showed a constant value and observed no further tendency to swell, the soil specimens were taken out from the oedometer cell and the water was drained. The wet specimens were let to air dry in a $25^{\circ} \mathrm{C}$ temperature controlled room, with no surcharge. This method was in good agreement with $[8,11,16,18]$. The mass of soil specimens were weighed at different time intervals until constant values were achieved. Dimensions of the soil samples (diameter and height) were measured at each time interval. After completion of drying period, the same soil samples were placed in the consolidometers for the subsequent swelling cycle. This procedure was repeated 7 and 8 times for NS and NZ samples respectively, in order to observe the effect of wetting and drying cycles on the swell-shrink behavior.

Variations of temperature affect the volume change behavior of swelling-shrinking soils. Therefore, three different temperatures $\left(25^{\circ} \mathrm{C}, 40^{\circ} \mathrm{C}\right.$ and $\left.60^{\circ} \mathrm{C}\right)$ were applied to selected soil samples which are NS (28-day) and NZ (28-day). Two of one-dimensional consolidometers were modified to accomplish tests under elevated temperatures and two fiber consolidation cells, were designed and produced in the workshop. The reason of choosing this material is due to being a light and refractory material, resistant to high temperatures, hence more suitable than metallic cells.

\section{Test Results and Discussions}

\subsection{Cyclic swell-shrink}

Cyclic swell-shrink test results are presented in Figure 1 and 2 for NS (28-d) and NZ (28-d) samples respectively. It can be seen from Figure 1 that the highest swell and shrinkage values were recorded at the $2^{\text {nd }}$ cycle for NS sample after which the swell strain showed a decreasing trend. Addition of sand or low-plastic materials to the expansive soil causes an interaction between particles and swelling reduces [18]. The significant reduction in both swell potential and axial shrinkage were obtained after the $5^{\text {th }}$ cycle, which is consistent with the findings of [8]. Swell potential results of $6^{\text {th }}$ and $7^{\text {th }}$ cycles were lower than the result of $1^{\text {st }}$ cycle and are quite close to each other. From these results one can interpret that equilibrium state has been reached after the $5^{\text {th }}$ cycle for NS specimens.

In NZ samples, there is a tendency for decreasing in both swell potential and axial shrinkage after the $5^{\text {th }}$ cycle and $63 \%$ and $67 \%$ reduction in swelling and shrinkage respectively were obtained at the $8^{\text {th }}$ cycle. Zeolite contains high amount of silica, therefore has a pozzolanic character. Pozzolanic reaction takes place between expansive soil and zeolite and this reaction leads to binding of particles, and the texture of soil mixture becoming more granular. The binding particles form cementation in the soil and this process causes the reduction in the swelling ability [25]. This behavior was observed after the $5^{\text {th }}$ cycle in NZ mixture and it can be stated that NZ samples reached the equilibrium at the $5^{\text {th }}$ cycle.

As a result, swelling potential and axial shrinkage decreased with the increment of wetting-drying cycles in both NS and NZ samples. The biggest change in axial strain (both swell and shrinkage) occurred at the $7^{\text {th }}$ cycle for NS (28-d) and the $8^{\text {th }}$ cycle for NZ (28-d). 


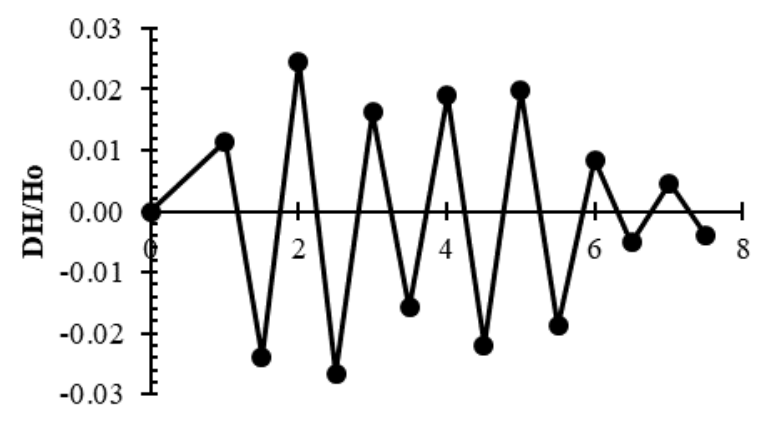

Number of cycles

Fig 1. Variation of axial strain due to wetting-drying cycles of NS (28-d).

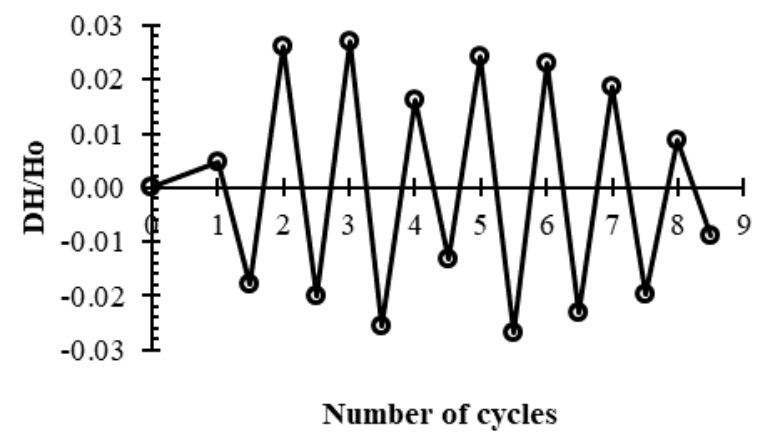

Fig 2. Variation of axial strain due to wetting-drying cycles of NZ (28-d).

\subsection{Temperature Effect}

\subsubsection{One-Dimensional Swell}

Swell potential (\%) versus time (min) graphs were obtained from one-dimensional swell tests conducted at $25^{\circ} \mathrm{C}, 40^{\circ} \mathrm{C}$ and $60^{\circ} \mathrm{C}$ on 28 -day cured NS and NZ soil groups, and the results are shown in Figure 3 and Figure 4. Test results are summarized in Table 3.

Swell test results showed that primary swell reduced with the increase of temperature in NS group which is also stated by $[23,27,31,32]$ however, a reverse behavior observed in NZ group. Swelling potential of $\mathrm{NZ}$ group increased at elevated temperatures and this behavior can be attributed to the increment of repulsion between clay platelets at micro level due to temperature increase, which can be explained by diffuse double layer (DDL) theory, hence causing increase in swelling capacity [33]. Increasing temperature caused a salient decrease in the completion of primary swell time for both NS and NZ groups. The largest reduction has occurred between the temperatures of $25^{\circ} \mathrm{C}$ and $40^{\circ} \mathrm{C}$ and which continued to reduce gradually until $60^{\circ} \mathrm{C}$.

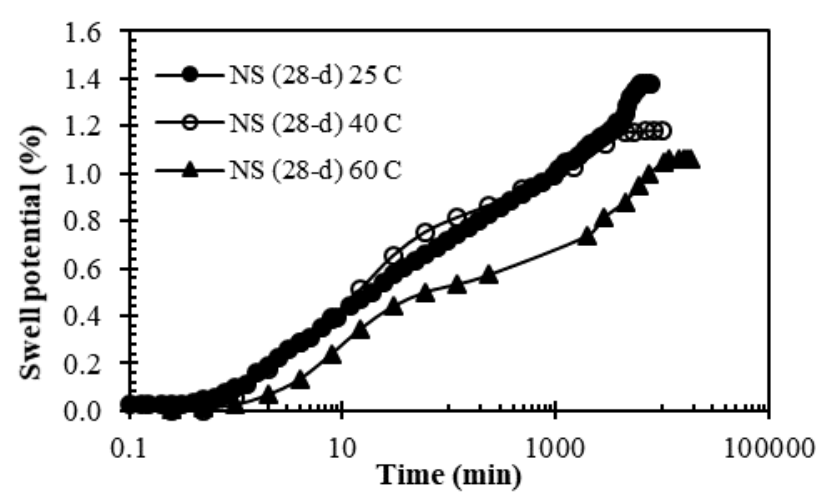

Fig 3. Swell curves for different temperatures of NS (28-d).

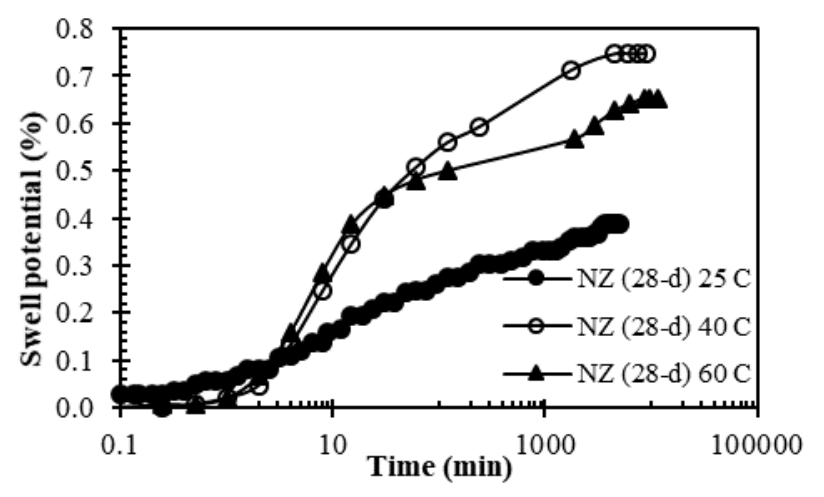

Fig 4. Swell curves for different temperatures of NZ (28-d).

Table 3. Swell test results.

\begin{tabular}{|l|c|c|}
\hline & $\begin{array}{c}\text { Primary swell } \\
\text { potential }(\%)\end{array}$ & $\begin{array}{c}\text { Time } \\
(\mathbf{m i n})\end{array}$ \\
\hline NS $\left(\mathbf{2 5}^{\circ} \mathbf{C}\right)$ & 1.20 & 4000 \\
\hline NS $\left(\mathbf{4 0}^{\circ} \mathbf{C}\right)$ & 0.76 & 60 \\
\hline NS $\left(\mathbf{6 0}^{\circ} \mathbf{C}\right)$ & 0.44 & 30 \\
\hline NZ $\left(\mathbf{2 5}^{\circ} \mathbf{C}\right)$ & 0.38 & 3500 \\
\hline NZ $\left(\mathbf{4 0}^{\circ} \mathbf{C}\right)$ & 0.48 & 35 \\
\hline $\mathbf{N Z ~}\left(\mathbf{6 0}^{\circ} \mathbf{C}\right)$ & 0.46 & 22 \\
\hline
\end{tabular}

\subsubsection{Consolidation}

Consolidation curves which are obtained from onedimensional compressibility tests (ASTM D2435-11) are shown in Figure 5 and 6 and the compressibility characteristics were listed in Table 4.

There is no significant variation of the compression index and rebound index values with the increase of temperature and this conclusion is consistent with the findings of previous researchers [28, 29]. 


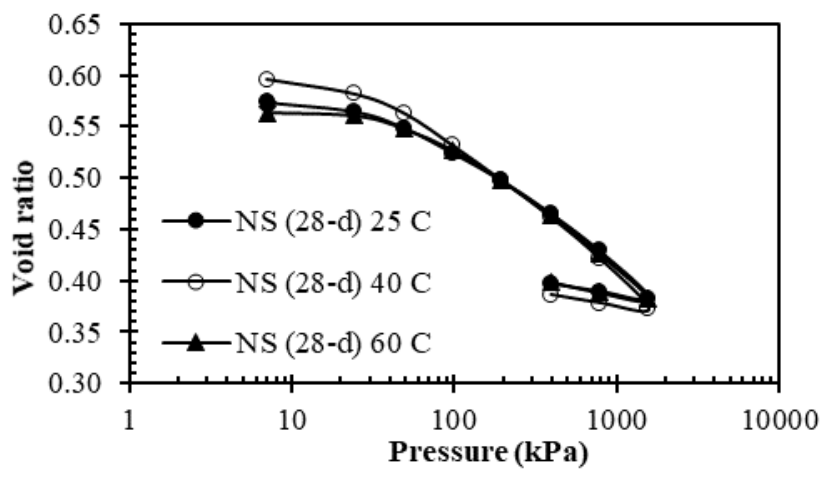

Fig 5. Consolidation curves at different temperatures for NS (28-d).

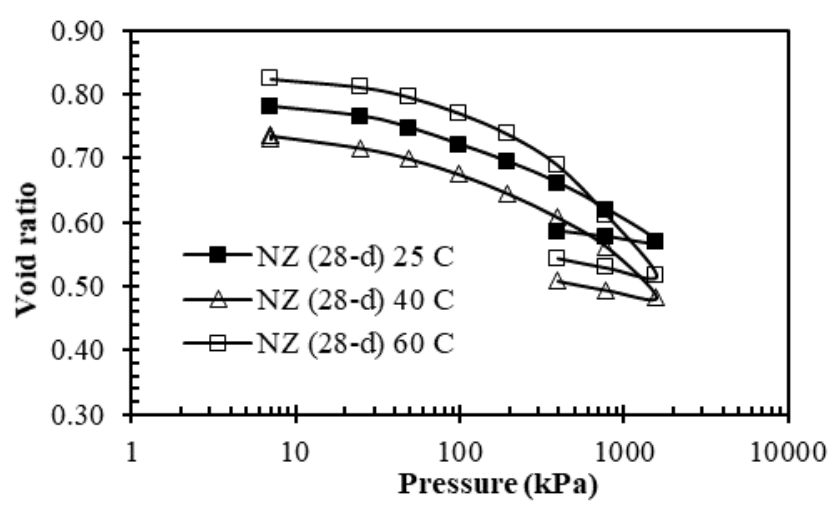

Fig 6. Consolidation curves at different temperatures for NZ (28-d).

Table 4. Compressibility characteristics of all soil groups.

\begin{tabular}{|l|c|c|}
\hline Material & $\mathbf{C}_{\mathbf{c}}$ & $\mathbf{C}_{\mathbf{r}}$ \\
\hline $\mathbf{N S}\left(\mathbf{2 5}^{\circ} \mathbf{C}\right)$ & 0.124 & 0.023 \\
\hline $\mathbf{N S}\left(\mathbf{4 0}^{\circ} \mathbf{C}\right)$ & 0.112 & 0.030 \\
\hline $\mathbf{N S}\left(\mathbf{6 0}^{\circ} \mathbf{C}\right)$ & 0.112 & 0.030 \\
\hline $\mathbf{N Z ~}\left(\mathbf{2 5}^{\circ} \mathbf{C}\right)$ & 0.145 & 0.030 \\
\hline $\left.\mathbf{N Z ~ ( 4 0}{ }^{\circ} \mathbf{C}\right)$ & 0.148 & 0.054 \\
\hline $\mathbf{N Z ~}\left(\mathbf{6 0}^{\circ} \mathbf{C}\right)$ & 0.128 & 0.025 \\
\hline
\end{tabular}

Saturated hydraulic conductivity values were calculated for different confining pressure ranges as given in Table 5. Hydraulic conductivity of NZ group showed an increasing trend with the increment of temperature due to the reduction of water viscosity which is agreeing with the findings of [26, 30, 33, 34]. However, hydraulic conductivity of NS group raised when temperature increased from $25^{\circ} \mathrm{C}$ to $40^{\circ} \mathrm{C}$, then decreased with the application of $60^{\circ} \mathrm{C}$. Therefore, a consistent behavior was not observed in NS group. However, hydraulic conductivity of NS at all temperature ranges and pressure ranges remained below the regulatory limit, whereas NZ does not satisfy this requirement at any temperature for confining pressures less than $196 \mathrm{kPa}$.
Table 5. Saturated hydraulic conductivity results.

\begin{tabular}{|l|c|c|c|c|}
\hline \multicolumn{5}{|c|}{$\mathbf{k}_{\text {sat }}(\mathbf{c m} / \mathbf{s})$} \\
\hline Soil group & $\begin{array}{c}\mathbf{9 8 - 1 9 6} \\
(\mathbf{k P a})\end{array}$ & $\begin{array}{c}\mathbf{1 9 6 - 3 9 2} \\
(\mathbf{k P a})\end{array}$ & $\begin{array}{c}\mathbf{3 9 2 - 7 8 4} \\
(\mathbf{k P a})\end{array}$ & $\begin{array}{c}\mathbf{7 8 4 - 1 5 6 8} \\
(\mathbf{k P a})\end{array}$ \\
\hline NS $\left(\mathbf{2 5}^{\circ} \mathbf{C}\right)$ & $4.27 \times 10^{-8}$ & $2.33 \times 10^{-8}$ & $1.34 \times 10^{-8}$ & $8.77 \times 10^{-9}$ \\
\hline NS $\left(\mathbf{4 0}^{\circ} \mathbf{C}\right)$ & $7.18 \times 10^{-8}$ & $4.67 \times 10^{-8}$ & $2.78 \times 10^{-8}$ & $1.45 \times 10^{-8}$ \\
\hline NS $\left(\mathbf{6 0}^{\circ} \mathbf{C}\right)$ & $3.90 \times 10^{-8}$ & $2.18 \times 10^{-8}$ & $1.29 \times 10^{-8}$ & $7.67 \times 10^{-9}$ \\
\hline NZ $\left(\mathbf{2 5}^{\circ} \mathbf{C}\right)$ & $1.44 \times 10^{-7}$ & $6.35 \times 10^{-8}$ & $4.02 \times 10^{-8}$ & $2.61 \times 10^{-8}$ \\
\hline NZ $\left(\mathbf{4 0}^{\circ} \mathbf{C}\right)$ & $1.13 \times 10^{-7}$ & $6.89 \times 10^{-8}$ & $4.37 \times 10^{-8}$ & $3.82 \times 10^{-8}$ \\
\hline NZ $\left(\mathbf{6 0}^{\circ} \mathbf{C}\right)$ & $1.14 \times 10^{-7}$ & $8.63 \times 10^{-8}$ & $7.07 \times 10^{-8}$ & $4.46 \times 10^{-8}$ \\
\hline
\end{tabular}

\section{Conclusions}

The effect of wetting-drying cycles on swelling potential and axial shrinkage of NS and NZ were investigated. In addition, influence of temperature on the swelling, compressibility characteristics and hydraulic conductivity of 28 days cured samples of NS and NZ were studied and the following conclusions were obtained.

1) Swelling potential and axial shrinkage were reduced with the increasing of wetting-drying cycles of both NS and NZ samples. The biggest variation of swell potential and axial shrinkage occurred at $7^{\text {th }}$ cycle for NS (28-d) soil specimen and $8^{\text {th }}$ cycle for NZ (28-d) soil sample. More cracks and deformation were observed in the NZ samples.

2) Primary percent swell decreased with the increase of temperature in NS group however, a reverse behavior was observed in NZ group. A marked decrease was observed in the completion of primary swell time in both NS and NZ groups. The biggest reduction has occurred between the temperatures of $25^{\circ} \mathrm{C}$ and $40^{\circ} \mathrm{C}$.

3) There was no significant change in the compression index and rebound index values with the increment of temperature.

4) Hydraulic conductivity of NZ group showed an increasing trend with the increasing temperature due to the reduction of water viscosity. However, a remarkable change was not observed with the temperature increment in NS group.

\section{References}

1. B.P. Warkentin, M. Bozozuk, Proceedings of $5^{\text {th }}$ International Conference on Soil Mechanics and Foundation Engineering, Dunod, Paris, Vol. 1, pp. 851-855 (1961)

2. F.H. Chen, Proceedings of Engineering Effects of Moisture Changes in Soils. International Research and Engineering Conference on Expansive Clay Soils, Texas, A \& M Press (1965)

3. T.Y. Chu, C.H. Mou, Proceedings of $3^{\text {rd }}$ International Conference on Expansive Soils, Haifa, Vol. 2, pp. 177-185 (1973) 
4. X.Q. Chen, Z.W. Lu, X.F. He, Proceedings of $11^{\text {th }}$ International Conference on Soil Mechanics and Foundation Engineering, Vol. 4, San Francisco, pp. 2389- 2392 (1985)

5. F.H. Chen, G.S. Ma, Proceedings of $6^{\text {th }}$ International Conference on Expansive Soils: 127-129, New Delhi (1987)

6. K.S.S. Rao, G.C. Satyadas, Proceedings of $6^{\text {th }}$ International Conference on Expansive Soils, Vol. 1, New Delhi, India, pp. 137-142 (1987)

7. A.F. Dif, W.F. Bluemel, Geotech. Test. J., 14(1), 96-102 (1991)

8. A.S. Al-Homoud, A.A. Basma, A.I. Husein Malkawi, M.A. Al-Bashabsheh, J. Geotech. Eng., ASCE, 121, 7, 562-565 (1995)

9. M. Popescu, Proceedings, 4th International Conference on Expansive Soils, Vol. 1, Denver, CO, pp. 158-171 (1980)

10. V.I. Osipov, N.B. Nguen, N.A. Rumjantseva, Appl Clay Sci, 2, 363-374 (1987)

11. R.W. Day, J Geotech Eng, 120, 3, 618-623 (1994)

12. H. Bilsel, E.R. Tuncer, Proceedings of International Conference on Problematic soils, Yanagisaiva, Moroto, and Mitachin, Eds., pp.337-340 (1998)

13. K.S.S. Rao, S. Tripathy, Geotech Test J, 26, 1, 36-46 (2003)

14. S.M. Rao, B.V.V. Reddy, M. Muttharam, Eng Geol, 60, 223-233 (2001)

15. F. Akcanca, M. Aytekin, Environ Earth Sci, 66, 67-74 (2012)

16. A.A. Basma, A.S. Al-Homoud, A.I. Husein Malkawi, M.A. Al-Bashabsheh, Appl Clay Sci, 11 (2-4), 211- 227 (1996)

17. B.A. Albrecht, C.H. Benson, J. Geotech. Geoenviron. 127, 1, 67-75 (2001)

18. E. Kalkan, Appl Clay Sci, 52, 345-352 (2011)

19. M.K. Widomski, W. Stępniewski1, R. Horn, A. Bieganowski, L. Gazda, M. Franus, M. Pawłowska, Int Agrophys, 29, 365-375 (2015)

20. S. Tripathy, K.S.S. Rao, D.G. Fredlund, Can Geotech J, 39, 938-959 (2002)

21. S. Tripathy, K.S.S. Rao,. Cyclic swell-shrink behaviour of a compacted expansive soil. Geotech Geol Eng, 27, 89-103 (2009)

22. F. Akcanca, M. Aytekin, Environ Earth Sci, 72, 59-66 (2014)

23. A. Lloret, M.V. Villar, Phys Chem Earth, 32, 701-715 (2007)

24. E. Romero, M. Villar, A. Lloret, Eng Geol, 81, 255-268 (2005)

25. A.R. Estabragh, M.R.S. Pereshkafti, B. Parsaei, A.A. Javadi, Int J Pave Eng, 14, 4, 418-427 (2013)

26. M.V. Villar, R. Gómez-Espina, A. Lloret, J Rock Mech and Geotech Eng, 2, 1, 71-78 (2010)

27. N. Shariatmadari, S. Saeidijam, Electron J Geotech Eng, 16, 137-146 (2011)

28. P. Delage, Y.J. Cui, A.M. Tang, J Rock Mech Geotech Eng, 2, 2, 111-123 (2010)
29. M. Kholghifard, K. Ahmad, N. Ali, A. Kassim, R. Kalatehjari, F. Babakanpour, (2014). J Croatian Assoc Civ Eng, 66, 3, 191-196.

30. W-J. Cho, J-O. Lee, K.S. Chun, Appl Clay Sci, 14, 47-58 (1999)

31. M.V. Villar, A. Lloret, Appl Clay Sci, 26, $337-$ 350 (2004)

32. A.R. Estabragh, F. Khosravi, A.A. Javadi, Environ Earth Sci, 75, 657 (2016)

33. W.M. Ye, M. Wan, B. Chen, Y.G. Chen, Y.J. Cui, J. Wang, Environ Earth Sci, 68, 281-288 (2013)

34. A. Tsutsumi, H. Tanaka, Soil Found, 52, 2, 207-215 (2012) 